\title{
Emphasizing the significance of site investigation for infrastructural development of the Greater-Jos Master Plan
}

\author{
Hannatu Nanman Wazoh \\ Department of Geology, University of Jos \\ PO Box 2084, Jos, Plateau State, Nigeria \\ *e-mail: wazohh@unijos.edu.ng,hannatuwazoh@gmail.com
}

\begin{abstract}
The rapid urbanization of the Jos Metropolis is giving rise to an increase in housing development and other infrastructures resulting in the reduction of the most favourable ground available for urban expansion. In view of this fast expansion, the Government of Plateau State through the Ministry for Urban Development created 'the Greater-Jos Master Plan' currently domiciled at the outskirt of the Jos city where negligible lands are being developed. However, these negligible areas are largely covered with soils which could be problematic in addition to being located adjacent to unstable slopes or even abandoned mine workings with high capacity for subsidence. The Greater-Jos Master Plan is aimed at facilitating adequate planning and control of the metropolis to accommodate the increasing population and reduce proliferation of slums in future. For safe and efficient development of this plan, it is important that subsoil conditions be properly investigated prior to commencement of the final design and construction activities. The present study seeks to compliment this laudable objective by emphasizing the need for an engineering site investigation for acquiring information on which the foundation of such structures and ancillary objects can stand and hence facilitating the proper take-off of the Greater-Jos Master Plan.
\end{abstract}

Keywords: Baseline Data, Geotechnical, Infrastructural development, Jos, Master Plan, Significance, Site Investigation.

DOI: $10.7176 / \mathrm{CER} / 13-6-04$

Publication date: November $30^{\text {th }} 2021$

\subsection{Introduction}

In view of rapid urbanization, the Government of Plateau resulted to creating 'The Greater-Jos Master Plan' where neglected lands are being utilized for commercial, residential, recreational, educational etc. purposes. The Greater-Jos Master Plan covering Jos North, Jos South, Parts of Jos East, Bassa, Barkin Ladi, and Riyom Local Government Areas (Figure 1) proposed by the Plateau State Government through the Ministry for Urban Development is aimed to facilitate adequate planning and control the metropolis to accommodate the growing population and reduce proliferation of slums in future. The Greater-Jos Master Plan area has been sub-divided into ten (10) sectors of various sizes totalling about $1,362 \mathrm{Km}^{2}$ based on such specific criteria as potentials for growth, existing community homogeneity, physical configuration and spatial locations. It is expected that each sector would be developed holistically with the existing development serving as the nucleus of each sector with all the attributes of Mini Urban Centre having all the attributes of a self sustained town. The major land use plan of the master plan is residential; hence it is intended to organize the global residential environments within the Greater-Jos Metropolis to create for new residential environments and reorganize the old ones in such ways as to achieve maximum residential 


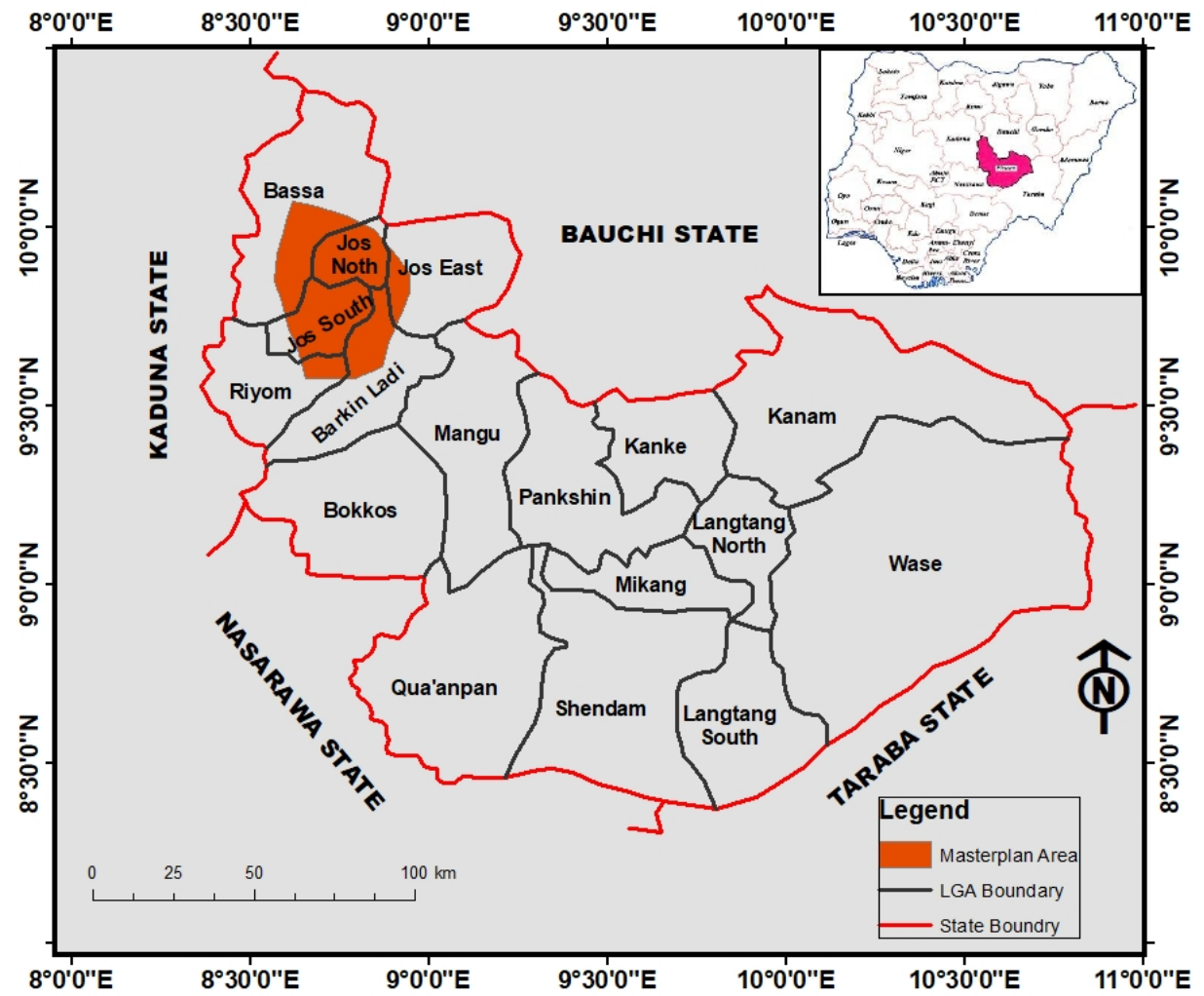

Figure1 Map showing areas covered by the Master Plan (modified after Fola Konsult, 2009)

satisfaction by prospective users of the different environments (Fola Konsult, 2009). In the distribution of services, facilities and amenities it is anticipated that the proposed sector centres will reduce pressure on the city centre through the provision of commercial facilities, health facilities, educational facilities at the neighbourhood level, tourism and recreation, industries, public land uses and facilities (like library, police station, fire facilities, post offices, large religious facilities, and cemeteries).

However, the areas on which this development will take place are largely covered with soils which could be problematic soils and may be located adjacent to unstable slopes or may be areas that were previously used for mine workings such as open mine pits, subsurface mine pits (loto), trenches, mine waste dumps and other mine affluent/relics (Mallo et al., 2011). These areas are probable areas of limitations and collapsing which must be adequately identified and defined. The Jos-Plateau tin fields which have been exposed to mining activities and environmental degradation that spanned over a decade since mining started in 1902 has left the land abandoned with mine pond, overburden (mine spoil) and processing mill wastes (Mallo, 2007). The development area is littered with several mine spoils and ponds in addition to severe erosion of the landmass which present serious limitation to urban expansion and agricultural development amongst others. However, large parcels of land have been reclaimed from mining pits which have not stabilized for urban development and are currently under plantation and these reclaimed lands are left as land reserve and green open spaces awaiting their stabilization for urban development (Fola Konsult, 2009).

Krebs \& Zipper (2009) suggest that special attention be given to engineering construction located in mineout areas, because of long term settlements resulting from the heavy weight of the ground itself. Also, The Greater-Jos Master Plan admits the requirements for stable foundations for roads, buildings, dams, bridges, masts and other civil structures; and hence suggests soil investigations/soil material testing and reports for design purposes to ascertain the engineering behaviour of the soils. Furthermore, literature review on the engineering properties on the Jos-Plateau reveals that soil investigation from an engineering point of view has been greatly overlooked; although these soils are being used as major source of construction material and for foundation of structures (Wazoh \& Mallo, 2021). Except for Government owned projects, study of the behaviour of these soils has been neglected by the general public. The designing and building of structures entails a thorough understanding of properties of available soils and rocks that will constitute the foundation and other constituents of the structures (Faseki et al., 2016). Information about the surface and subsurface features is necessary for the 
design of structures and for planning construction techniques (Roy \& Bhalla, 2017). Therefore, for proper design of the foundation of civil engineering structures in the implementation of the Greater-Jos Master Plan, subsurface site characterization will be required to provide subsurface information. It is in this regard that emphasis on the need for engineering site investigation is being considered in this paper.

\subsection{A Review of Literatures of Site Investigations as Related to the Jos-Plateau}

A compendium on the geotechnical properties of major problem soils of Nigeria which includes mostly: the black cotton soils of north-eastern Nigeria; clay shale of north-western Nigeria; organic clay prominent in Lagos and soft sedimentary deposits of the Niger-delta areas of Nigeria, compiled by Bolarinwa (2010); Bolarinwa \& Ola (2016); Okagbue et al. (2018) can be accessible when dealing with soils. The findings of this works can be used as a guide for the preliminary choice and design of foundations on soils. Further study by Adejumo et al. (2012) presented an overview of the basic physico-mechanical properties of some Nigerian weak soils that is intended to serve as guiding factors for the preliminary choice and design of foundations for buildings and other structures. The physico-mechanical properties of weak soils in Nigeria cover wide ranges. According to the study, vertisols (black cotton soils) have physico-mechanical properties which produce high swelling and shrinkage potentials to the soils. These properties which are also not to a lesser degree exhibited by the Sokoto soft clay shale, determine the type of foundations and construction methods/measures employed on the soils. The Gombe soils as studied by Mallo et al. (2012) also confirm these varying engineering properties of the soils indicating fair to good engineering materials. The south-west organic clay has physico-mechanical properties which impact high compressibility to the soils. These properties influence the type of foundations and construction methods/measures employed on the soils. Foundations on these soils are design to limit compressibility (excessive settlement) problem to the barest minimum. Kekere et al. (2012) showed that problems soils are the major causes of road failure though poor engineering construction also contributes to the incessant road failures. However, Okagbue et al. (2018) revealed poor construction materials and lack of geophysical investigation as major causes of building collapse in Nigeria. Also, foundation types and construction methods used on the soils are controlled by other factors such as permeability, angle of shearing resistance and bearing capacity, clay and resistivity, plasticity and soil characterization. Oyeyemi et al. (2020) also revealed the lack of adequate information about the near-surface characterization prior to construction as a contributing factor to incessant building collapse and foundation failures. If adequate information is obtained prior to construction, it will guide in building design, foundation type, settlement rate and sub-soil bearing capacity.

Geophysical methods, particularly electrical resistivity technique had been used extensively for a wide variety of engineering and environmental problems (Zohdy, 1975; Barker, 1980; Mousa, 2003, Olorunfemi, et al., 2004; Hosny et al., 2005; Alotaibi \& Al-Amri, 2007; Nigm et al., 2008; Oyedele et al., 2009). The most important is the existence of a significant and detectable contrast between the physical properties of the different units in the subsurface, such as velocity, electrical resistivity, conductivity, density, acoustic properties, subsurface geology and the environmental conditions (Soupios \& Kokinou, 2016). According to Oyodele et al. (2015), geophysics in engineering studies provides either a 2 or 3-dimensional subsurface image of an area when compared with an in-situ geotechnical survey which gives discontinuous 1-dimensional information for the subsurface conditions. Useful information on hazardous subsurface conditions especially hidden near-surface structures such as cavities/or inhomogeneity in foundation geo-materials has been revealed by geophysical methods (Malehmir et al., 2013). The application of electrical resistivity survey has become a main preference in engineering construction because of its proficiency, cost-effectiveness and its resolution/capacity of marking out subsurface geology effectively (Longpia et al., 2013; Oyedele et al., 2015; Ayodele, 2017). Amadu et al. (2018) employed the electrical resistivity method in rock fracture characterization and termed it as economic, efficient and less time consuming in contrast to other subsurface fracture characterization method such as core drilling. It has been used to determine geological structures (Al-Sayed \& El-Qady, 2007), to examine structural weaknesses and to characterize soil conditions that reveal geo-electric sequences characterized by resistivity and thickness (Ibitoye et al., 2013; Oyedele et al., 2011). It has been applied in different geological environment where a 2-D resistivity survey was used to map the stratigraphy and structures of a shallow subsurface effectively as reported by Nordiana et al. (2013). It has been applied in foundation studies by Olorunfemi et al. (2004) to determine the possible cause(s) of foundation failure. The geo-electric and geologic parameters of the subsurface revealed differential settlement facilitated by clays at depth to be responsible for the foundation failure. These studies have indicated the usefulness of geophysical investigation (electrical resistivity) in determining the subsurface condition of an area.

Integrated techniques of both geotechnical and geophysical site investigations are significant tools in engineering site description. According to Ojo et al. (2015) subsoil competence of foundation materials can be established through an integrated geophysical and geotechnical studies thereby categorizing an area into zones of competency. It is in this regard that Omowumi (2014) used vertical electrical sounding (VES) at a proposed 
building site in Ibese southwest Nigeria to ascertain the geo-electrical layer characteristics used to evaluate the structural competence of the subsurface geological characteristics of the site for construction purposes and building development. To further reiterate the importance of foundation investigation in building and engineering structures, an integrated geophysical and geotechnical investigation was carried out at a proposed switch station for a telecommunication mast at a site in the south eastern parts of Nigeria by Akintorinwa \& Adesoji (2009). The geophysical survey employed the vertical electrical sounding technique using Schlumberger configuration while the geotechnical aspect involved the drilling of boreholes at locations strategically distributed within the survey site. Although Cone Penetration Test (CPT) provided useful information, this information is limited to the location of the measurement. The result of the geotechnical survey was used as a control to the geophysical interpretations (Avwenagha et al., 2014; Oyedele et al., 2011). Hence, geophysical investigation is not a substitute for boring and direct physical testing; rather it complements a well-planned, rapid, cost-effective drilling and provides a volumetric image of the subsurface rather than a point of measurement (Adepelumi \& Olorunfemi, 2000; Roberto et al., 2004 and Oyedele \& Bankole, 2009). Employing integrated geophysical and geotechnical methods usually offer very fast and relatively less expensive approach for characterizing the subsurface for engineering foundation. Consequently, Olayanju et al. (2017) employed the vertical electrical sounding (VES), very low frequency electromagnetic method (VLF-EM) and dipole-dipole surveys in conjunction with geotechnical methods for foundation integrity assessment. These methods corroborated the subsoil layer results revealing the area to be of low competence and poor materials. Information on size, depth and changes which are often overlooked in geotechnical investigation were captured in the integrated studies through the geophysical investigation. Hence, geophysical investigation is able to complement the geotechnical investigation in terms of size, lateral coverage, depth and shape or discontinuity across an area of interest (Arisona et al., 2020).

Subsurface investigation of the ground conditions involving engineering geophysics and geotechnical studies is mostly accompanied with groundwater condition and lineaments evaluation. Groundwater observation is an important aspect of geotechnical site investigation. Akinwade et al. (2020) underscore the importance of acquiring groundwater condition information alongside engineering geologic properties for engineering foundation. The intent is to allow for evaluation of seasonal variations in groundwater levels (Baxter et a1., 2005) for the purpose of foundation design and construction purpose. The variation in groundwater level will not only affect the geostatic stress within the depths of engineering significance but also the water balance of an area (Abam, 2016). Jones \& Jefferson (2012) noted that the seasonal variation in water content is mostly responsible for expansive soil problems. The water content in soil is mostly due to one of the under listed factors: high water table, poor drainage under foundations, leaks due to sewer failure or poorly managed runoff and irrigation and garden watering. The impact of groundwater on foundation can be evaluated from this information.

The information provided by geophysical subsurface investigations on subsurface geological structures can be complemented by lineaments evaluation. Lineaments studies have been employed in engineering studies for the understanding of hidden architecture of the bedrock for foundation stability (Wolosiewicz, 2018). According to Prabhakaran \& Jawahar Raj (2018), lineament studies can identify geologically weak zones that could be hazardous to some engineering structures. Areas with high fracturing, shearing, intensity of deformation, groundwater yield and soil erodibility are linked to high lineaments density and intersections. Such areas are considered unsuitable for construction of civil engineering structures such as dams and reservoirs.

The compendium on the engineering properties of soils in Nigeria as compiled by these previous studies did not include much information on the Jos-Plateau. As a topic of empirical investigation, the engineering site investigation of the Jos-Plateau has received relatively little attention since the work of Lar et al. (2011) on the characterization of the lateritic soils of part of Jos-Plateau and environs. This study reiterates the significance of geotechnical properties of lateritic soils and how it affects the characterization and usability in the construction industry. In an attempt to address the lack of understanding/neglect of the properties of soils used in civil engineering construction work on the Plateau, Sule et al. (2021) examine the index properties of sub-soil along the Jos-Makurdi road. The study established the need for modification of the soils for suitability in engineering construction. Other studies that attempted a geotechnical characterization and usability of the soils in the JosPlateau are the works of Chukwuma (2010); Ryeshak et al. (2015); Wazoh et al. (2016); Wazoh (2017) and Wazoh \& Mallo (2021). According to Chukwuma (2010), the geotechnical properties of properly reclaimed mine-out lands improved tremendously in comparison to areas that have not been properly reclaimed. Wazoh (2017) concentrated on built up areas within the Greater-Jos Master plan areas with focus on specific engineering structures such as roads and buildings, revealing the soils to be of low to medium swelling potential and medium compressibility making the soils good engineering materials. Ryeshak (2015) recommended the use of raft or piles for foundations of the facilities at the Plateau State University, Bokkos in order to address the problem of compressibility. It is in this regard that Wazoh et al. (2016) offered possible suggestions in overcoming further failures in a section of road within the Greater-Jos Master Plan. The failure of civil engineering structures in some parts of Jos and environs necessitated the assessment of the geotechnical properties of lateritic soils by 
Vincent et al. (2020). The study revealed the soils from the northern part of the Jos-Plateau to be unsuitable for most civil engineering constructions due to the silty-clayey nature and therefore classified the soils as fair and poor but good sub-base materials. Daku et al. (2019) provided an insight into the potentiality of soils to corrosion around some parts of Jos North. Based on a direct relationship between earth resistance and soil corrositivity of the tested soils, the area was sub-divided into non-corrosive to slightly corrosive. This information is to serve as guide in underground infrastructure such as metallic pipes, tanks against the possibility of corrosion. Though, not much information is available on the performance of lateritic soils on the Jos-Plateau, most of the literature discussing the performance of the soils as materials of construction did not make any reference to subsurface information such as subsurface geology in relation to engineering structures. It is therefore against this backdrop that geophysical survey in relation to engineering site investigation is apt for understanding of the size, lateral extent and variations of the subsurface soil in order to avoid instability/failures in the implementation of the Greater-Jos Master Plan.

\subsection{Geology and Geomorphology of the Jos-Plateau}

The Basement Complex rocks and the Younger Granites are the major rock types that underlie the JosPlateau (Figure 2).
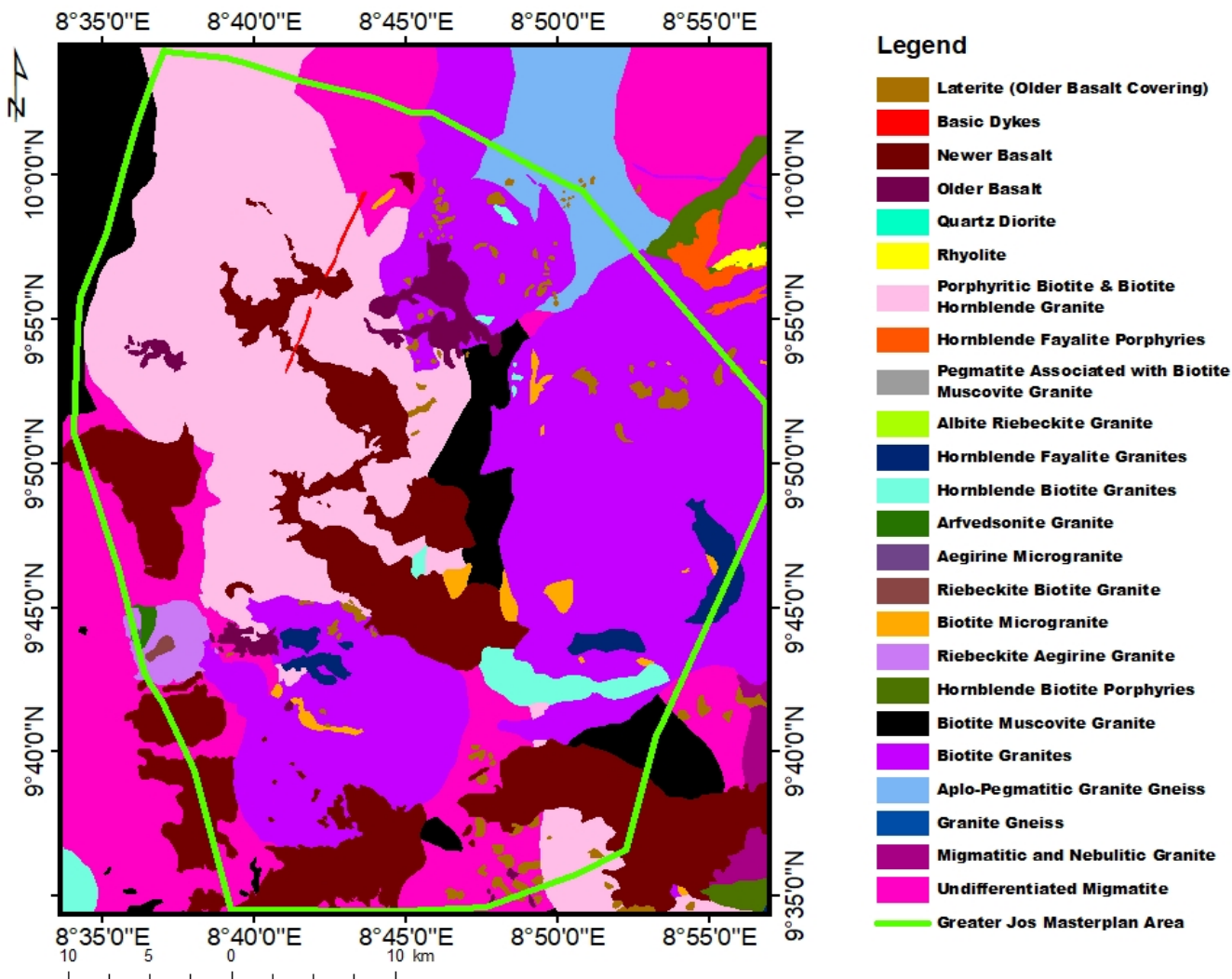

Figure 2 Geology Map of Nigeria (Modified after Geological Survey Agency of Nigeria, 2012)

Geologically, the Jos-Plateau is a part of the Precambrian to Mid-Cambrian $(600 \pm 150 \mathrm{Ma})$ Basement Complex, and Jurassic (150 Ma) northern Nigerian crystalline shield (Schoeneich \& Mbonu, 1991). The Basement Complex rocks of the lower Paleozoic Precambrian ages underlie about half of its entire landmass. These rocks are represented by gneiss-migmatites and intrusive into these basement rocks are the predominant Jurassic nonorogenic alkaline Younger Granites (Turner, 1976). The Jurassic Younger Granite Ring Complexes are dominated by the high level of intrusion of granites and are emplaced into the Pan - African Basement rocks on swells representing the roof zones of caldera collapse type ancient volcanoes, whose early stage of eruption developed roughly circular ring fractures. Tertiary and Quaternary basaltic volcanic are the youngest rocks in the area and overlie directly the basement and in places the Younger Granites (Wright, 1976). The Greater-Jos Master Plan area is underlain by less than $10 \%$ Precambrian Basement Complex rocks which occupy valleys and lowland areas. In some places the Basement Complex rocks has been intruded by Precambrian to Late Paleozoic Pan-African Granites (Older Granite), diorite and charnockites which occupy about 20\% of the surface. The 
Younger Granites Ring Complex rocks which occupy nearly 50\% of the Jos-Plateau intruded into the basement rocks in an N-S trend (Onyeanuna, 2017). The granites of the Jos-Plateau are made up of alkali feldspar granites in association with rhyolites, minor gabbros and syenites (Szentes, 2009). They occur as sub-volcanic intrusive complexes of ring dykes and related annular and cylindrical intrusions (Ejeh \& Ugbe, 2010). The Jos-Plateau is the highest platform in Nigeria with an elevation of between $1500-1800 \mathrm{~m}$ above sea level. The area is characterized by impressive ridges and inselbergs separated by plains. The Shere hills with an average height of $1400 \mathrm{~m}$ to the north-east of Jos provide the peak at an elevation of 1766m (Fola Konsult, 2009). The Jos-Plateau is situated in the upper plateau with many rock outcrops. Likewise around Jos, there are many dug pits with their resultant ponds from mining activities.

The Guinea Savanna is the prevailing vegetation in the Jos-Plateau. But due to the peculiar location at high altitude of the plateau, the vegetation cover is slightly different. It consists of trees, shrubs, and short grasses characteristics of the montane vegetation with tall trees at the foot of the plateau and short grasses at the peak (Fola Konsult, 2009).

\subsection{SIGNIFICANCE OF ENGINEERING GEOLOGICAL SITE INVESTIGATION TO THE GREATER JOS MASTER PLAN}

A thorough geotechnical site exploration is important in the implementation of any development project such as the Greater-Jos Master Plan. This will provide information on design and construction and environmental assessment. According to Budhu (2004), a site investigation program will provide an assessment of the general suitability of the site for proposed structures. It foresees against difficulties that may arise during construction. It is important that an engineering geological investigation be carried out in the implementation of the Greater-Jos Master Plan because the information obtained will enable an engineer to reach conclusion on the suitability of the site for infrastructure. According to Wazoh \& Mallo (2014), the design criteria, construction problems, groundwater conditions and environmental impact of the structures to be constructed can be better understood during a site investigation. Consequently, an engineering geological site investigation will help in the general understating of the subsurface condition of soils and rocks in the following ways:

a. It will give insight into the subsurface geology and engineering site characterization through which lithologic units and their geo-electric layer characteristics down to competent bedrock will be delineated. The lithological characteristics of the subsurface geology will guide in ensuring proper foundation for stability from the top through the bedrock layer.

b. Identifying the presence of geologic structures such as fractures and other weak zones that may have implications on engineering structures.

c. Determine the engineering geological properties of the subsurface soils thereby providing information on the behaviour of soils regarding their strength, consistency behaviour, grain size, rate of settlement, etc. and their implications on foundation stability for engineering structure.

d. Determine the groundwater conditions and its effect on stability of engineering structures.

e. Determine the suitability of materials for construction.

f. Evaluate the suitability of the subsurface soils for any engineering construction.

g. It will provide baseline data for preparation of construction plans and specifications for the Greater-Jos Master Plan. This can assist in proper urban development and land use planning, regulating development in areas which are prone to instability. It will be used as a guide for the expected remedial action to be taken in improving stability against structural failures.

\subsection{PROPOSED SITE INVESTIGATIONS TECHNIQUES FOR THE GREATER-JOS MASTER PLAN}

According to Blyth \& de Freitas (2005), site investigation contains numerous activities that make up its components. It usually commences with a 'desk study' to collate existing data, topographic and geological maps, satellite images and literature reviews of works and projects in the area. A visit to the site will be necessary to collate all the data so far obtained, and to identify areas where engineering difficulties may exist and areas where particular investigations are needed. Thereafter, a good preliminary report should be compiled to assist the ensuing investigation and provide a basis for the final report.

\subsection{In situ Investigation}

3.1.1 Surface Investigation

Geological Mapping: A geological investigation should be done to ascertain the information provided by the existing geological map of the area. This is to identify and understand the characteristics of the foundation soils and the level of bedrock and any other geologic conditions that may influence design, construction, and long term performance of any engineering structure. Geological mapping will establish the general geologic setting of the area such as the topography, lithological boundaries, rock units, fractures and faults. The 
groundwater conditions and soil profile should be observed and described during this stage. Areas previously mined and being reworked should be identified and marked for the possibility of subsidence and settlement. Satellite images or aeromagnetic data can be used to identify significant geological features.

\subsubsection{Subsurface Investigation}

Because of the significance and the size of the master plan in relation to engineering construction and urban planning, geophysical exploration should be included in the site investigation. This is an indirect method of subsurface investigation where geologic information is obtained by using special instruments to measure certain physical properties. Geophysical observations in themselves are not geologic truth, but are statistical and systematic measurements. Hence they complement core drilling, test pits or other direct methods of subsurface exploration and can provide a rapid evaluation of certain geologic conditions. According to Bell (2007), geophysical survey will help to locate the position of boreholes or drill holes and also detect variations in subsurface conditions between the holes. Geophysical exploration should be used to determine the geological sequence and structure of subsurface rocks and soils. The electrical resistivity technique would be more cost effective, less time consuming and easy to carry out, hence it is recommended for this project (Longpia et al., 2013; Oyedele et al., 2015; Ayodele, 2017). It is essential, therefore, that the results obtained are correlated with borehole data to yield a high standard of results.

The direct methods of investigation through excavation of trial pits, trenches or shafts should be used for ground assessment, testing and sampling for further testing in the laboratory. Common in-situ testing that can be used include: density replacement test which measures the in-situ density of soil; Penetrometer tests (standard penetration tests and cone penetration tests) which measures the resistance to penetration offered by the soil at any depth thereby providing information on the relative density, shear strength and bearing capacity of the soil; Shear vane test which measures the undrained shear strength in clays; Load test which provides information by which the bearing capacity and settlement characteristics of a foundation can be assessed; Pressure tests which measures the reaction of a rock mass to stress over large areas, giving values of Young's modulus, elastic recovery, inelastic deformation and creep and in-situ shear test provide an estimate of the angle of shearing resistance (Smith, 2014; Bell, 2007; Blyth \& de Freitas, 2005).

\subsubsection{Soil Sampling}

Soil and rock samples should be taken regularly during the ground investigation so that specific ground properties required in the geotechnical design can be established. A major consideration during sampling a particular stratum is to ensure that the sample taken is appropriate for the tests required (Smith, 2014). To ensure accurate and reliable test results, the quality of the sample must therefore be appropriate for that particular test. The soil samples obtained for observation and laboratory tests should be undisturbed and disturbed. Undisturbed samples, which are required mainly for shear strength and consolidation tests, are obtained by techniques which aim at retaining the in-situ structure and water content of the soil (Craig, 2004). Bell (2007) described disturbed sample as one having the same particle size distribution as the in-situ soil but in which the soil structure has been significantly damaged or completely destroyed. Disturbed samples, which are used mainly for soil classification tests, visual classification and compaction tests, can be excavated from trial pits or obtained from the tools used to develop boreholes. Samples in which the natural water content has been preserved should be placed in airtight containers and should be clearly labeled.

\subsection{Laboratory Tests}

It is essential that laboratory testing of materials be performed as an integral part of the site investigation to determine index (classification tests) properties, density, compaction, consolidation and settlement characteristics, strength and permeability. Beavis (1985) recommends special tests such as dispersion, stabilization and clay mineralogy and chemistry under special circumstances. For rocks, strength and deformation (elasticity and creep) tests, shear parameters, durability and permeability tests are basic. If rock is to be used as road aggregate or a concrete aggregate, the rock will need to be tested to ascertain its appropriateness for the purpose.

\subsubsection{Soil Classification or Index Tests}

Index tests are the most basic types of laboratory tests performed on soil samples (Craig, 2004). Index tests include the water content (also known as moisture content), specific gravity tests, unit weight determinations, particle size distributions and Atterberg limits, which are used to classify the soil. These tests are carried out to give information about the engineering properties of soils on a site in order to classify the soils. They tend to provide information on soil behaviour, soil strength, stability ad settlement rate.

\subsubsection{Strength and Consolidation Tests}

Strength and consolidation tests can be performed both on the field and in the laboratory. The main purpose 
of consolidation test is to obtain soil data which is used in predicting the rate of settlement of structures. Four important soil properties furnished by consolidation tests are preconsolidation stress, compression index, recompression index, coefficient of consolidation. The compressive properties of a soil are usually determined in the laboratory by a consolidation test (ASTM D-2435-70).

\subsubsection{Compaction Tests}

This laboratory test is performed to determine the relationship between the moisture content and the dry density of a soil for a specified compactive effort (Mohammed, 2014). The compactive effort is the amount of mechanical energy that is applied to the soil mass. Several different methods are used to compact soil in the field, and some examples include tamping, kneading, vibration, and static load compaction. The main objectives are to increase shear strength and therefore bearing capacity and to increase stiffness and therefore reduce future settlement. Soil compaction can be a very economical method of soil improvement, and it is often used to make ground suitable for the foundations of roads and to prepare a level surface for building construction. It is also used in the placing of soil fills and in the construction of earth dams to ensure suitable soil properties.

\subsubsection{Shear Strength Tests}

The shear strength of a soil is a basic geotechnical engineering parameter and is required for the analysis of foundations, earthwork, and slope stability problems (Day, 2006). This is because of the nature of soil, which is composed of individual soil particles that slide (i.e., shear past each other) when the soil is loaded. The shear strength of the soil can be determined in the field (e.g., vane shear test) or in the laboratory.

3.2.5 Chemical Test of Soil and Water

The soil organic matter content, sulphate content of soil and water, the $\mathrm{pH}$ value of a soil and the electrical resistivity of a soil affect the soil in one way or the other. The chemical content determines the strength of the soil. The strength of dry inorganic soil is significantly greater than that of the organic. The presence of sulphate in the soil may react with cement during any construction and thereby reduce the strength of the structure. Chemical test will help determine possible contamination which may have consequences for foundation design and the general suitability of the site for the proposed project. Remote sensing (infra-red photography) and geophysical technique (conductivity testing) can be useful in assessing possible contamination (Craig, 2004). Soil and groundwater samples can be obtained from trial pits or borehole for $\mathrm{pH}$, sulphate and other chemical tests.

\subsubsection{Groundwater Observations}

Bell et al., (1986) emphasized the importance of investigating the effects that the changes in the groundwater regime will have on the engineering performance of soil and rock masses for foundation stability prior to engineering construction. As an important part of any ground investigation, the water table level or the artesian pressure in particular strata should be determined. Static water level defines the elevation of the water table which is the top of the saturated zone in an unconfined aquifer or elevation of the potentiometric surface (imaginary plane) in a confined aquifer (Taylor \& Alley, 2001). Groundwater observations are of particular importance if deep excavations are to be carried out. Water table level can be determined by measuring the depth to the water surface in a borehole or hand dug wells. The groundwater flow direction which may affect the quality of water and indicate recharge and discharge areas should also be established.

\subsubsection{Borehole Logs}

After an investigation has been completed and the results of any laboratory tests are obtainable, the ground conditions revealed in each borehole (or trial pit) should be summarized in the form of a borehole log (Craig, 2004). A borehole $\log$ is a list of all the materials encountered during the boring. A log is best shown in sectional form so that the depths at which the various materials were met can be easily seen and is prepared with reference to a vertical scale. The log will enable a rapid appraisal of the soil profile to be made. A typical borehole log should include a note of all the information that was found: groundwater conditions, numbers and types of samples taken, soil profile, list of in-situ tests, time taken by boring, etc. (Smith, 2014). The log can be correlated with the geophysical results to produce a high standard of results.

\subsubsection{Site Investigation Report}

Report providing relevant information retrieved during the site investigation must be compiled as a written report. According to Smith (2009), the report should include an account of the desk study, the series of laboratory testing results, the field investigation, sampling and measurement reports, the field testing reports, groundwater condition and any other relevant reports, together with an interpretation of the ground conditions across the site. The borehole log should also be included in the report. The report will also include any limitations and constraint of the various test results so that the designer can assess the relevance of the test results to the geotechnical 
design.

\subsection{CONCLUSION}

The benefits of carrying out a comprehensive engineering site investigation for any urban development with emphasis on the Greater-Jos Master Plan area have been reported in this paper. Phases of site investigation involving in-situ and laboratory techniques, groundwater observation and reporting were emphasized. The benefit of this approach will provide a baseline data that can be used for construction plan in the implementation of the Greater-Jos Master Plan. In the light of the foregoing, it is very important that property developers do not undertake any engineering construction without first performing a thorough geotechnical investigation of the proposed site. This is not an end itself but a means to an end. Hence, further investigation may be undertaken as construction commences and foundation rocks and soils become exposed and unforeseen ground conditions which may require further investigation may be revealed.

Acknowledgement

The preparation of this report benefited from the background information of the Greater-Jos Master Plan as compiled by Fola Konsult Nigeria Ltd.

\section{References}

Abam, T. K. (2016). Engineering Geology of the Niger Delta. Journal of Earth Sciences and Geotechnical Engineering, 6(3), 65-79.

Adejumo, T., Alhassan, M., \& Boiko, I. (2012). Physico-mechnaical properties of some major weak soils in Nigeria. Electronic Journal of Geotechnical Engineering, 17, 2435-2441.

Adepelumi, A. A., \& Olorunfemi, M. O. (2000). Engineering geological and geophysical Investigation of the reclaimed Lekki peninsula, Lagos, Southwestern, Nigeria. Bulletin of Engineering and Environment, 58(2), 125-131.

Akintorinwa, O., \& Adesoji, J. (2009). Application of geophysical and geotechnical investigations in engineering site evaluation. International Journal of Physical Sciences, 4(8), 553-454.

Akinwade, J.T., Fakolade, Q. R., \& Aderinola, O. S. (2020). Sub-soil investigation of a proposed construction site at Ado-Ekiti, South Western Nigeria. Journal of Multidiciplinary Engineering Science and Technology, 7(1),11471-11476.

Alotaibi, A.M. and AlAmri, A.M. (2007). Ground water potentialities of Wadi Malakan- Southern Makkah AlMokadash City, Saudi Arabia. Geophysical Society Journal, 5(1), 101-116.

Al-Sayed, E. A., \& El-Qady, G. (2007). Evaluation of sea water intrusion using the electrical resistivity and transient electromagnetic survey: Case study at Fan of Wadi Feiran, Sinai, Egypt. Paper Presented at the International Workshop on Innovation in Electromagnetic, Gravity and Magnetic Methods (EGMM), Capri, Italy.

Amadu, C. C., Gawu, S. K. Y., \& Abanyie, K. S. (2018). Experimental study of electrical resistivity to rock fracture intensity and aperture size. International Journal of Physics, 6(3), 85-92. https://doi.org/10.12691/ijp-6-3-4

Arisona, A., Ishola, K. S., \& Nawawi, M. N. M. (2020). Subsurface void mapping using geophysical and geotechnical techniques with uncertainties estimation: case study of Kinta valley, Perak, Malaysia. Springer Nature Journal, Applied Sciences, 2(117), 1-12. https://doi.org/10.1007/s42452-020-2967-X

Avwenagha, E. O., Akpokodje, E. G., \& Tse, A. C. (2014). Geotechnical properties of subsurface soils in Warri western Niger Delta, Nigeria. Journal of Earth Sciences and Geotechnical Engineering, 4(1), 89-102.

Ayodele, M. O., Omoirabor, O., \& Adiela, U. P. (2017). An investigation of the relationship between electrical resistiivty (Wenner and Schlumberger arrays) and geotechnical parameters in foundation investigation in Basement Complex area of Iloko, Osun state, Nigeria. International Journal of Scientific Engineering and Science, 1(5), 18-23.

Barker, R. D. (1980). Application of geophysics in groundwater investigations, Water Survey, 84, 489-492.

Baxter, C.D., Page, M., Bradshaw, A. S., \& Sherril, M. (2005). Guidelines for Geotechnical site investigations in Rhode Island (Tech. Rep. No. 0103). Retrieved August 2020, from https://www.researchgate.net/publication/237460404.

Beavis, P. K. (1985). Engineering Geology. London: Blackwell Scientific Publications.

Bell, F. G. (2007). Engineering Geology. Amsterdan: Elsevier Ltd.

Bolarinwa, A. (2010). Geotechnical properties of major problem soils of Nigeria. Retrieved September 2013, from http://engrdemol.hubpages.com/hub/geotechnical-properties-of-Nigerian-soils.

Bolarinwa, A., \& Ola, S. A. (2016). A review of the major problem soils in Nigeria. FUOYE Journal of Engineering and Technology, 1(1), 20-25.

Blyth, F. G., \& de Freitas, M. H. (2005). A Geology for Engineers. London: Elsevier Butterworth- Heineman. 
Budhu, M. 2004) Foundations and earth structures (draft). http://www.ic.arizona_edu/ic/ce440/site\%20characterization.pdf.

Chuwkuma, R. C. (2010). Geotechnical properties of reclaimed mine out land sites: a case study of Jos and environs, Sheet $168 N E$ and SE. Unpublished master's thesis, University of Jos, Jos.

Craig, R. F. (2004). Craig's Soil Mechanics. London: Spon Press.

Daku, S. S., Diyelmak, V. B., Otitolaiye, O. A., \& Abalaka, I. E. (2019). Evaluation of soil corrosivity using electrical resistivity method: A case study of part of the University of Jos Permanent Site. Scientific Research Journal, 3(3), 66-76. https://doi.org/10.31364/SCIRJ/v7.13.2019.P0319623

Day, R. W. (2006). Foundation Engineering Handbook: Design and Construction with the 2006 International Building Code. New York: McGraw-Hill Companies, Inc.

Ejeh, O. I., \& Ugbe, C. F. (2010). Fracture systems in the Younger Granite rocks around Fobur, northern Nigeria: Product of residual stress? Global Journal of Geological Sciences, 8(1), 57-64.

Faseki, O. E., Olatinpo, O. A. \& Oladimeji, A. R. (2016). Foundation design at Addo, Lagos, Nigeria. Journal of Civil Engineering, 1, 12-25.

Fola Konsult Limited. (2009). Greater Jos Master Plan. Jos: Author.

Hosny, M. M., EZZ El-Deen, A. A., Abdel, R., \& Barseim, M. S. M. (2005). Geoelectrical study on the groundwater occurrence in the area Southwest of Sidi Barrani, Northwestern Coast, Egypt. Geophysical Society Journal, 3(1), 109-118.

Ibitoye, F. P., Ipinmoroti, F. V., Salami, M., \& Akinluwade, K. J. (2013). Application of geophysical methods to building foundation studies. International Journal of Geosciences, 4, 1245-1266. https://doi.org/10.423/ijg.2013.49120

Jennings, J. E., Brink, A. B. A., \& Williams, A. A. B. (1973). Revised guide to soil profiling for civil engineering purposes in South Africa. Transactions SAICE, 15.

Jones, L. D., \& Jefferson, I. F. (2012). Expansive soils. Institution of Civil Engineers Manual Series. Retrieved May 28, 2018 from, http://www.researchgate.net/publication/26774450.

Krebs, R. D., \& Zipper, C. E (2009). Foundation for housing and reclaimed mines land. Virginia Cooperative Extension Publication, 460 (115).

Lar, U. A., Wazoh, H. N., Mallo, S. J., \& Chup, A. S. (2011). Geotechnical characterization of lateritic soils in Jos and Environs. Nigerian Mining Journal, 9(1), 7-17.

Longpia, C. B., Ashano, E. C., \& Pam, B. G. (2013). Geophysical investigation for engineering site development around Galadimawa-Aleita Area, Abuja, North-Central Nigeria. IOSR Journal of Applied Geology and Geophysics, 1(6), 1-11.

Mallehmir, A., Bastani, M., Krawczyk, C. M., Gurk, M., Ismal, N., Polom, U., \& Persson, L. (2013). Geophysical assessment and geotechnical investigation of quick-clay landslides - a Sweeden case study. European Association of Geoscientist and Engineers, Near Surface Geophysic, 11, 341 -350.

Mallo, S.J. (2007). Minerals and Mining on the Jos Plateau. Jos: ACON Publishers.

Mallo, S. J., Wazoh, H. N., Aluwong, K. V., \& Elam, E. A. (2011). Artisanal mining of cassiterite: the subsurface (loto) approach, sheet 30, Rayfield Jos, Nigeria. Continental Journal of Environmental Sciences Wilolud, 5(2), $38-50$.

Mallo, S. J., \& Akuboh, I. A. (2012). Geotechnical investigation of soils: A case study of Gombe town (Sheet 152NW), North Eastern Nigeria. International Journal of Modern Engineering Research, 2(6), 4280 4286.

Mohammed, J. (2014). Soil and Soil Mechanics Textbook. https://doi: 10.13140/RG.2.2.31964.39047

Mousa, D. A. (2003). The role of 1-D sounding and 2-D resistivity inversions in delineating the near surface lithologic variations in Tushka area, south of Egypt. Geophysical Society Journal, 1, 57-64.

Nigm, A. A., Elterb, R. A., Nasr, F. E., \& Thobaity, H. M. (2008). Contribution of ground magnetic and resistivity methods in groundwater assessment in Wadi Bany Omair. Holy Makkah Area, Saudi Arabia, Egyptian. Geophysical Society Journal 6(1), 67-79.

Nordiana, E. T., Saad, R., Nawawi, M. N. M., Azwin, I. N., \& Mohammed, E. T. (2013). Case study: shallow subsurface geology mapping using 2-D resistivity imaging with EHR technique. Asian-Pacific Chemical, Biological \& Environmental Engineering Society, 5, 134-140. https://doi.org/10.1016/j.apcbee.2013.05.024

Ojo J. S., Olorunfemi M. O., Akintorinwa O. J., Bayode S., Omosuyi G. O., \& Akinluyi F. O. (2015). Subsoil competence characterization of the Akure metropolis, southwest of Nigeria. Journal of Geography, Environment and Earth Science International, 3(1), 1 - 14. https://doi.org/10.10973/JGEESI/2015/15851

Olorunfemi, M. O., Idoringie, A. I., Coker, A. T. A., \& Babadiya, G. E. (2004).The application of the electrical resistivity method in foundation failure investigation. Global Journal of Geological sciences, 2, 39-51.

Omowumi F. P. (2014). Application of electrical resistivity in building foundation investigation in Ibese 
Southwestern Nigeria. Asia Pacific Journal of Energy and Environment, 1(2), 95-106.

Oyedele, K. F., Ayolabi, E. A., Adeoti, L., \& Adegbola, R. B. (2009). Geophysical and hydrogeological evaluation of rising groundwater level in the coastal areas of Lagos, Nigeria. Bulletin of Engineering Geology and Environment, 68, 137 - 143.

Oyedele, K. F., Oladele, S., \& Adedoyin, O. (2011). Application of geophysical and geotechnical methods to site characterization for construction purposes at Ikoyi, Lagos, Nigeria. Journal of Earth Sciences and Geotechnical Engineering, 1(1), 87-100.

Oyedele, K. F., Oladele, S., \& Okoh, C. (2015). Assessment of subsurface conditions in a coastal area of Lagos using geophysical methods. Nigerian Journal of Technology Development, 12(2), 36-41.

Oyeyemi, K. D., Olofinnade, O. M., Aizebeokhai, A. P., A. P., Sanuade, O. A. Oladunjoye, M. A., Ede, A. N.,... Ayara, W. A. (2020). Geoengineering site characterization for foundation integrity assessment. Congent Engineering, 7(1), 1-16. https://doi.org/10.1080/23311916.2020.111684

Kekere, A. A., Lawal, L.O., \& Awotayo, G. P. (2012). Relationship between geotechnical properties and road failures along Ilorin - Ajase Ipo Road Kwara State, Nigeria. Journal of Mechanical and Civil Engineering (IOSR-JMCE), 4(4), 1- 4.

Roy, S., \& Bhalla, S. K. (2017). Role of geotechnical properties of soil on civil engineering structures. Journal of Resources and Environment, 7(4), 103-109.

Okagbue, H. I., Iroham, C. O., Peter, N. J., Owolabi, J. D., Adamu, P. I., \& Opanya, A. A. (2018). Systematic review of building failure and collapse in Nigeria. International Journal of Civil Enginering and Technology, 9(10), 1391-1401.

Olayanju, G. M. (2011). Engineering geophysical investigation of a flood zone: A case study of Alaba Layout, Akure, southwestern Nigeria. Nigeria Journal of Geology and Mining Resource, 3(8), 193-200.

Omowumi F. P. (2014). Application of electrical resistivity in building foundation investigation in Ibese Southwestern Nigeria. Asia Pacific Journal of Energy and Environment, 1(2), 95-106.

Onyeanuna, C. A. (2017). Interpretation of ring structures in Jos Plateau using Nigeria Sat 1 imagery. International Journal of Mathematics and Physical Sciences Research, 4(2), 95-104.

Oyedele, K. F., \& Bankole, O. O. (2009). Subsuface stratigraphic mapping using geophysics and its impact on urbanization development in Arepo area, Ogun State, Nigeria. New York Science Journal, 2(2), 31-45.

Oyedele, K. F., Oladele, S., \& Adedoyin, O. (2011). Application of geophysical and geotechnical methods to site characterization for construction purposes at Ikoyi, Lagos, Nigeria. Journal of Earth Sciences and Geotechnical Engineering, 1(1), 87-100.

Oyedele, K. F., Oladele, S., \& Okoh, C. (2015). Assessment of subsurface conditions in a coastal area of Lagos using geophysical methods. Nigerian Journal of Technology Development, 12(2), 36-41.

Prabhakaran, A., \& Jawahar Raj, N. (2018). Mapping and analysis of tectonic lineaments of Pachamalai hills, Tamil Nadu, India using geospatial technology. Geology, Ecology and Landscapes, 2(2), 81-103. https://doi.org/10.1080/24749508.2018.1452481

Roberto, B., Enrico, G., Federica, A., \& Giorgio, G. (2004). Geophysical approach to the environmental study of a coastal plain. Geophysics, 68(5), 1446-1458.

Ryeshak, A. G., Wazoh, H. N., \& Daku, S. S. (2015). The geological and geotechnical properties of earth materials of Plateau State University, Nigeria in relation to its suitability for facility layout. International Journal of Scientific and Engineering Research, 6(10), 19-22.

Schoeneich, K., \& Mbonu, W.C. (1991): Excursion guide book on the geology of the Jos-Plateau and Yankari Game Reserve. Jos: The Nigerian Mining and Geosciences Society (NMGS)

Smith, I. (2014). Smith's Elements of Soil Mechanics. UK: John Willey and Sons Ltd.

Soupios, P., \& Kokinou, E. (2016). Environmental geophysics: Techniques, advantages and limitations. In Aiello, G. (Ed.), Geophysics: Principles, Applications and Emerging Technologies (pp.13-47). USA: Nova Publisher.

Retrieved March, 2020 from https://www.researchgate.net/publication/298874887

Sule, E., Moude, E. H., Adamu,A. Y., \& Mailafiya, B. Y. (2021). Investigation of index properties of soils along Jos-Makurdi road in North central Nigeria. Saudi Journal of Civil Engineering, 5(4), 87-90. https://doi.org:10.36348/sjce.2021.v05i04.002

Szentes.G. (2009). Granite formations and granite cavities in Northern Nigeria. Cadernos Laboratorio Xeoloxia de Laxe, 34, 13-26. https://www.researchgate.

Turner, D. C. (1976). Structure and Petrology Complexes. In Kogbe, C.A., (Ed.), Geology of Nigeria. Jos: Rock View, Nigeria Ltd.

Vincent, E., Dominic, P., \& Kure, M. M. (2020). Assessment of geotechnical parameters of lateritc soil of Jos and environs, for civil engineering constructions North Central part of Nigeria. Nigerian Annals of Pure and Applied Science, 3(3), 222-239.

Wazoh, H. N. \& Mallo, S. J. (2014). Standard penetration test in engineering geological site investigations - a 
review. The International Journal of Engineering and Science, 3(7), 40-48.

Wazoh, H. N., Daku, S. S., \& Samuel, F. G. (2016). Investigative study of possible causes of failure of a section of road in Jos - Plateau, North Central Nigeria. Journal of Multidisciplinary Engineering Science Studies, 2(11), 1128-1132.

Wazoh, H. N. (2017). Compaction behaviour and classification properties of soils of Kwang/Shen, Jos-Plateau, North-central Nigeria. Journal of Multidisciplinary Engineering Science Studies, 3(2), 1405-1408.

Wazoh, H. N., \& Mallo, S. J. (2021). Implications of the engineering geological properties of soils in the Implementation of the Greater Jos Master Plan, North Central Nigeria. European Journal of Engineering and Technology Research, 6(5), 118-128. http://doi.org/10.24018/ejers.2021.6.5.2530

Wolosiewicz, B. (2018). The influence of the deep seated geological structures on the landscape morphology of the Dunajec River catchment area, Central Carpathians, Poland and Slovakia. Contemporary Trends Geosciences, 7(1), 21-47. https://doi.org/10.2478/ctg-2018-0002

Wright, E. P. (1971). The Basement Complex. Bulletin of Geological Survey of Nigeria, 1(32).

Wright, J.B. (1976). Volcanic rocks in Nigeria. In Kogbe, C. A. (Ed.), Geology of Nigeria. Jos: Rock View, Nigeria. Ltd.

Zohdy, A. R. (1975). Automatic interpretation of Schlumberger sounding curves using modified Dar Zarrouk functions. United State Geological Survey Bulletin, 1313, 39.

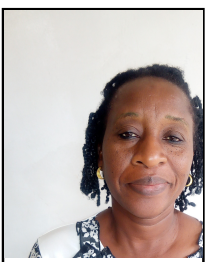

Hannatu NanmanWazoh holds a Bachelor Degree in Geology and Mining (1999), and a Master's degree in Hydrogeology/Engineering Geology (2010) from the Department of Geology, University of Jos, Nigeria.

She is a Lecturer with sixteen years' experience at the Department of Geology, University of Jos, Nigeria and a PhD Candidate in the same Department. Her research interests are in the field of engineering geology, engineering geophysics, hydrogeology and site investigation. She has published research papers in both local and internationally peer reviewed Journals.

Mrs. Wazoh is a Corporate Member of Nigerian Mining and Geosciences Society (NMGS), Registered Member of Council of Mining Engineers and Geoscientists (COMEG), and a Corresponding Member of the Young Members' Presidential Group (YMPG) of International Society for soil Mechanics and Geotechnical Engineers (ISSMGE). 